\title{
Analysis of the accuracy of horizontals estimated by different mapping methods
}

\author{
Agnẻ Bykovienè, \\ Daiva Gudritienė, \\ Vilma Sinkevičiūtè \\ Aleksandras Stulginskis University, \\ Studentu 11, \\ LT-53361 Akademija, Kaunas Distr. \\ E-mail:agnebykoviene@gmail.com; \\ gudritiene@gmail.com; \\ vilma.sinkeviciute@gmail.com
}

\begin{abstract}
The objective of this research is to analyse the accuracy of horizontals which are formed by different mapping methods and to create an accuracy analysis model of surface elevation formed by different methods. The research was carried out in three stages: 1) Choosing the territory and collecting spatial data; 2) Data processing; 3) Analysis of data. The research object is the relief of some part of the Pypliai Village which is in the Kaunas District. In respect of the relief it is a varied place of different expressiveness situated by the Nemunas River.

After the comparison of elevation data got by geodetic and analogical methods it was estimated that the total intersect area was 0.9581 ha (32\% of all investigative territory). When comparing the elevation model made by the geodetic method and the LiDAR method, it was estimated that elevation intersected in 1.2762 ha of the territory ( $43 \%$ of all investigative territory). In comparison of the elevation data of all three methods it was measured that the area of intersection was 0.5926 ha (only $20 \%$ of all investigative territory). It can be confirmed that the data is accurate in this territory - it intersects in all three mapping methods. The LiDAR elevation data is more accurate than the analogical model data. Nevertheless, the utmost 10 meters error is considerable while comparing to the geodetic model data, it occurs 10 times of 74 cases of comparison.
\end{abstract}

Key words: elevation errors, GIS, accuracy of horizontals, LIDAR, mapping, model, relief

\section{INTRODUCTION}

An analogical horizontal display method which signifies the relief was introduced in Lithuania in the end of the nineteenth century (Kazakevičius, 2000; 2001). After the measurements of the triangulation network maps have been prepared in the following ways: using the results of plane-table photos, creating instrumental reconnaissance of old maps, combined with using aerial photographs. The 1:10 000 scale map of the end of the Soviet period included nearly all the territory of Lithuania, became the starting material creating all scale topographical maps. Topographical maps of a scale of $1: 10000$ have been published since 1955 to 1991. The relief of these maps is used till now. It was digitized, copied, and moved into a database (e. g. KDB10LT). Digitized horizontals are now worldwide usable for creating digital terrain models (Kumetaitienè, 2005).
The three-dimensional position and size of objects are found using indirect measurements from photographic images taken from the ground, plane or satellite systems. With the development of computer equipment now aero photographic images can be processed digitally. The newly created LiDAR (Light Detection and Ranging), an effective laser scanning (probing) from the air method, has been recently put into use of gathering geographic information about earth's dimensional surface. The main reason for using LiDAR systems is that $\mathrm{Li}$ DAR is able to capture significant height (usually pitch is determined after processing) data arrays in a short period of time (Žalnierukas et al., 2006). Initial data collected by the LiDAR system is not only the information about earth's surface geodetic elevation but also about other natural and manmade objects in the earth's surface (e. g. vegetation, buildings, etc.). Therefore, LiDAR makes it possible 
to use remote probing in various branches of science. This technology is used to get high quality digital topographic terrain models, which can be used to develop models of cities and their maps. In this area LiDAR technology helps to develop such projects: the topographic data collecting, updating and maintaining cadastral data, tourism, wood register, and inventory of known and unknown surfaces, power line maintenance and planning, GIS and others, development of digital terrain models of oceans, coastal zones and wetlands, exploration of high-density areas of tall buildings (Barazzetti et al., 2007). LiDAR is also used in the mapping surface of Mars and analyzing earthquake possibility (Cunningham et al., 2006), ground deformations and landslides (Satkūnas et al., 2008).

Two major projects based on LiDAR scanning have been carried out in Lithuania. In 2007 spring in Lithuania by the order from the National Land Service under the Ministry of Agriculture a LiDAR photo of the district centers of 10 largest cities was made for the first time. And in 20092010 remote LiDAR scanning was carried out in the whole territory of Lithuania. The aim of the latter scanning was to develop the LiDAR database in a form of location (Digital Terrain Model, further on - DTM), data and land surface (Digital Surface Model, further on - DSM). In addition, the LiDAR database was used in production of orthophotographic maps. The required density of laser points was 0.5 point per square meter. The expected absolute accuracy was $0.50 \mathrm{~m}$, measured and verified on hard surface.

LiDAR remote scanning DTM and DSM data quality is acceptable and meets the quality level required for the project. However, is this data accurate at places of different expressiveness? And what are the noticeable changes when comparing old cartographic information and LiDAR data with geodetic measurements?

Therefore, the objective of this research is to analyse the accuracy of horizontals which are formed by different mapping methods and to create an accuracy analysis model of surface elevation formed by different methods.

\section{MATERIALS AND METHODS}

The research object is the relief of some part of the Pypliai Village which is in the Kaunas District (Fig. 1). In respect of the relief it is a varied place of different expressiveness situated by the Nemunas River. The following initial data was used: the cartographic database at scale 1: 10000 (KDB10LT) horizontals, laser scanning point data set and horizontals created in the geodetic method (a topographic map). All horizontals have a step of 5 meters. A digital orthophotographic map sheet "Raudondvaris" (nomenclature 57/37) at a scale of 1 : 10000 (ORT10LT) was used as an additional tool.

The research was carried out in three stages:

1. Choosing the territory and collecting spatial data;

2. Data processing;

3. Analysis of data.

The following scientific research methods were used to create an accuracy analysis model of surface elevation formed by different methods: an analysis of cartographic material, logical thinking, modeling, comparison and generalization of the data and graphic representation.

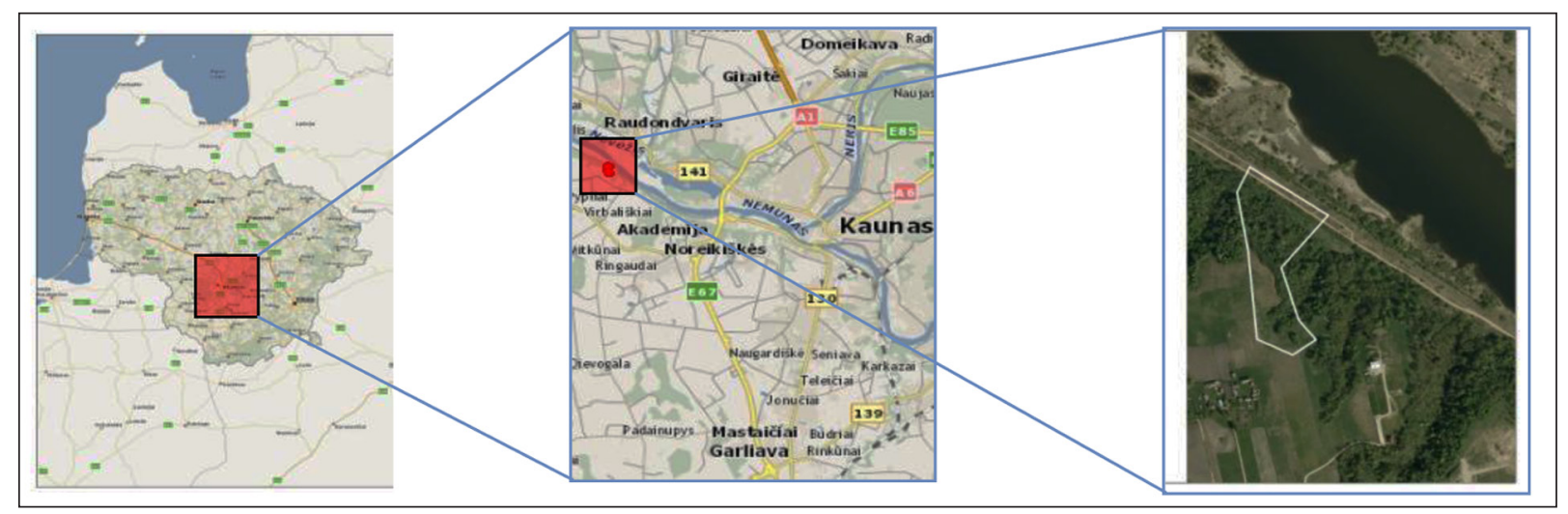

Fig. 1. Territory of interest 
The ArcGIS 10, GeoMap software was used to carry out the research and the Excel software was used for data processing.

\section{RESULTS AND DISCUSSION}

There are many aspects on which the accuracy of horizontals which are formed by different mapping methods is evaluable. Therefore in the first step of this research a new model was created. It was decid- ed that the following criteria should be evaluated if it is necessary to identify areas where horizontals height intersects: the height of horizontals, size of area, elevation errors, expressiveness of relief, land use. Therefore the main problem was to determine territories and areas where horizontals intersect and vary. Geographic information systems (GIS) as one of the tools for solving this problem were chosen. Figure 2 familiarizes with all analyses which were done to create a model in ArcMap step by step.

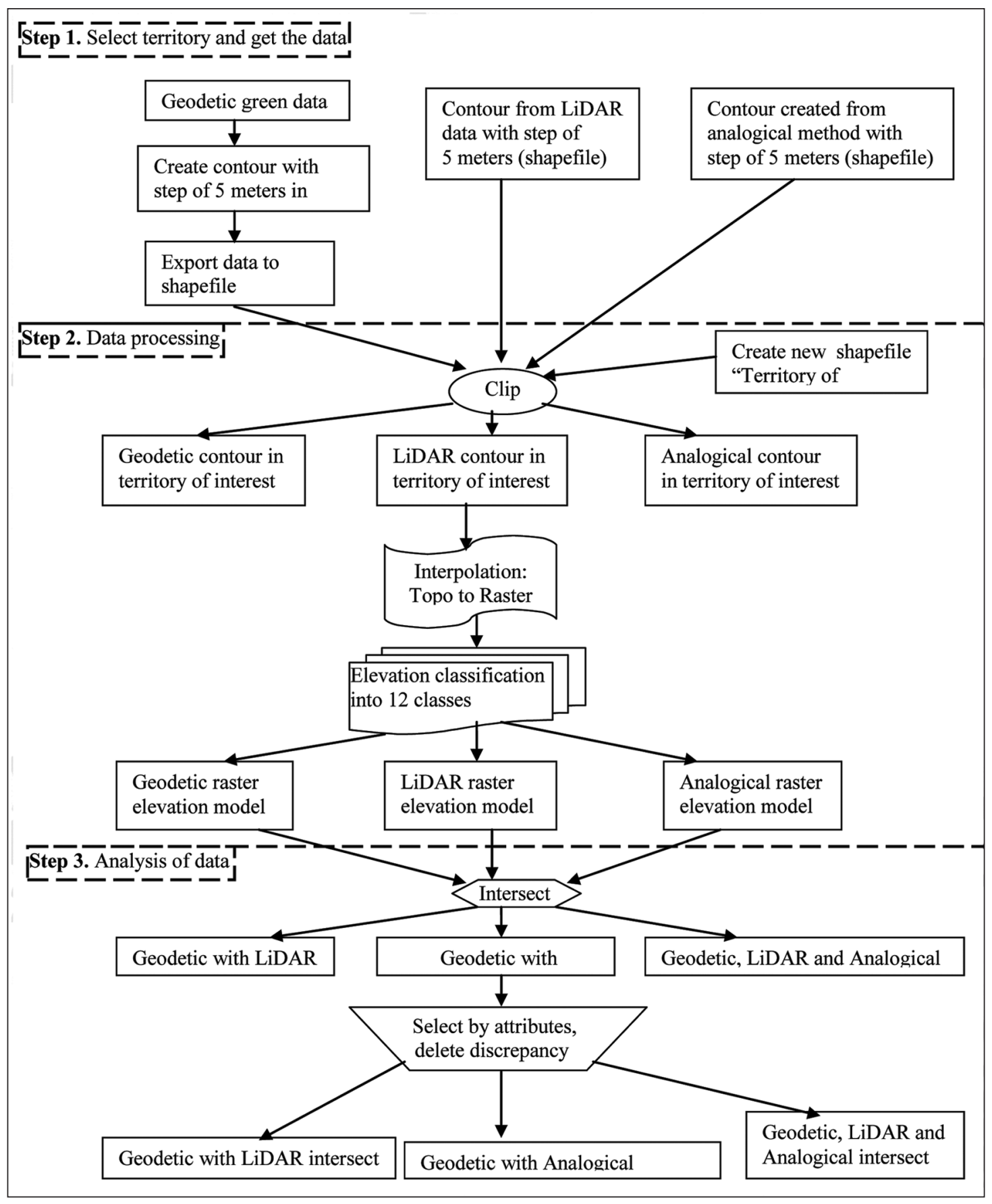

Fig. 2. The flowchart of the accuracy analysis model of surface elevation formed by different methods 
The 6.94 ha territory at the Pypliai Village had been measured by geodetic devices. Only 2.950 ha of it were used for the research. That territory was chosen because it had a miscellaneous natural situation (an open and wooded terrain) and an expressive relief.

First of all, primary data had been processed by the GeoMap program. It is the only program which can identify primary field measurements. Horizontals were created at the territory of research by using 215 measured points. 15 horizontals with a step of 5 meters had been drawn automatically. The file of the surface scheme is in a DWG/DXF vectorial data format. This format is common in the Computer Aided Design (CAD) software - Autodesk. The main research had to be done with the ArcGIS system so it was a must to convert data from the CAD to GIS format (Shapefile - a vectorial data format which uses SHP, SHX, and DBF files). It had been done in the first step of model creating (Fig. 2).

Analysed spatial data were processed in the second stage. It was done with the help of various tools of the ArcGIS software. The territory of interest was allocated (a new shapefile was created) to avoid loading the software. Only 2.950 ha of it were used for the research. That territory was chosen because it had a miscellaneous natural situation (an open and wooded terrain) and an expressive relief. Horizontals made by the Geodetic, LiDAR and Analogical methods in the territory of interest were created. It was done with the help of one of analysis tools - Clip. All of them are in three vectorial data layers. It is difficult to analyse accuracy if there are just vectorial elevation data. Therefore a Spatial Analyst tool "Topo to Raster" was used. This tool interpolates the raster surface from the line. Raster elevation models of the territory of interest were created. It was done to all three layers separately. New raster elevation models were classified into 12 elevation zones. They fit the interval of horizontals. For instance, the lowest elevation interval (25) includes 22.32 to 25 meters value. The highest elevation interval (80) includes 75 to 80 meters value. After all raster elevation models of relief mapping had been made, it was noticed that they definitely do not intersect (Fig. 3). There are visible differences not only in a flat and hilly terrain but also in a wooded and open area.

The geodetic method is considered the most accurate so it will be the basic data in further

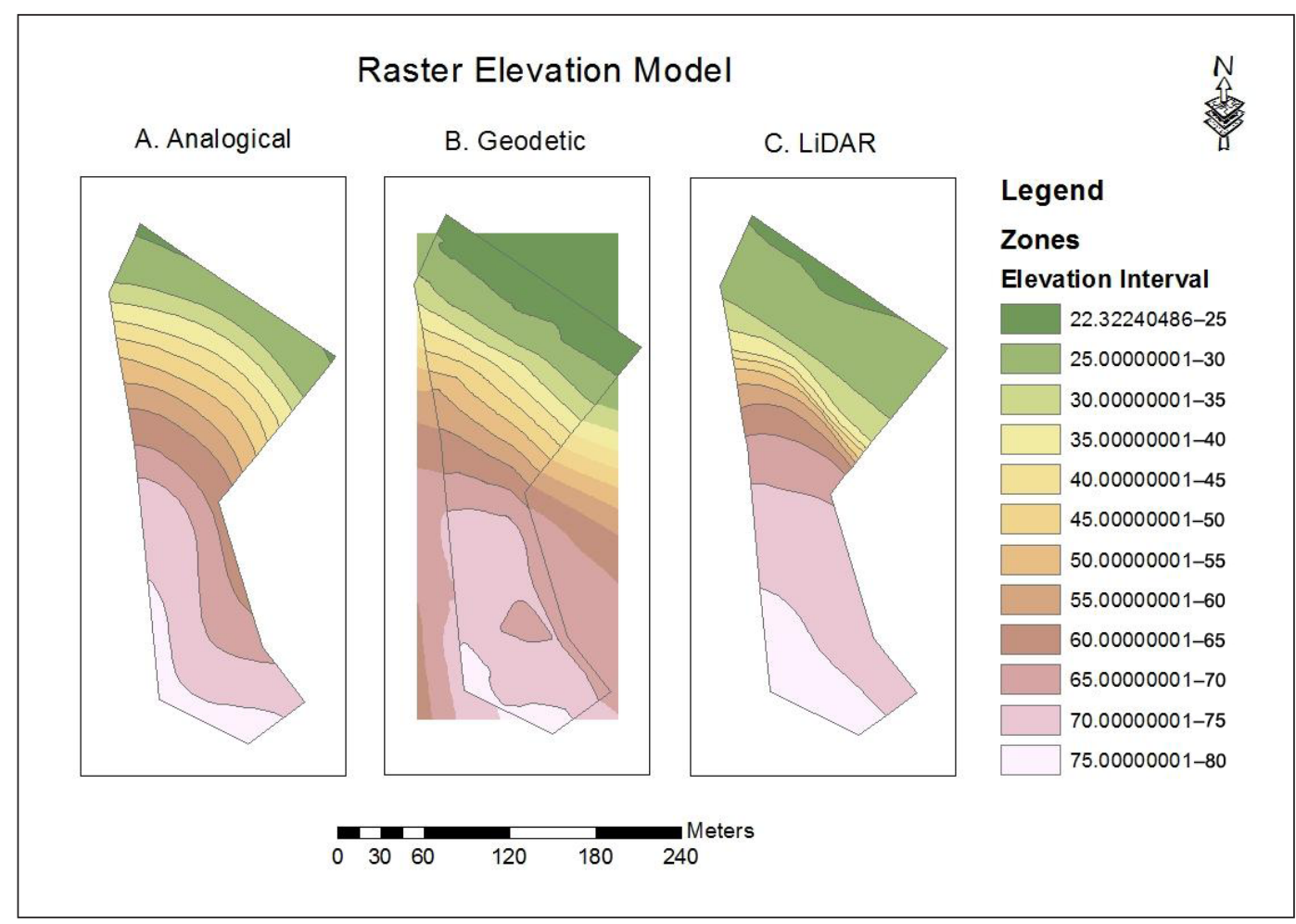

Fig. 3. Raster elevation models 
research. LiDAR and analogical methods had been compared in order to identify which method is more familiar with the basic one (geodetic vs. analogical and geodetic vs. LiDAR). It had been done in the final step - an analysis of data (Fig. 2). An ArcGIS analysis tool "Intersect" to carry out the analysis was chosen. It computes a geometric intersection of the input features.

The first comparison is between geodetic and analogical methods (Fig. 3, A and B). During the analysis of the investigative 2.950 ha territory it was estimated that there were 13 zones which elevation intersected more or less. 2 territories intersect in two elevation zones but there is a discrepancy in the elevation zone of 50-55 meters. The total intersect area is 0.9581 ha. It is $32 \%$ of all investigative territory (Fig. 4, A). The smallest area is $0.2 \mathrm{~m}^{2}$, the largest area is $0.5187 \mathrm{ha}$. The major part of the intersecting area is in flat and open territories. The most of discrepant territories are in a steep slope overgrown with deciduous woods.

When comparing the elevation model made by the geodetic method and LiDAR method (Fig. 3, B and C), it was estimated that the elevation intersected in 1.2762 ha of the the territory.
It is $43 \%$ of all investigative territory (Fig. 4, B). They are spread in 12 zones. There is an intersection in every elevation zone. The largest intersection areas are in a flat and open territory (0.3659 ha) and in a sparse forest territory with a slight slope $(0.4982 \mathrm{ha})$. There are many minor intersections of a small area in the slope overgrown with woods.

Additionally, a model for all three methods had been made (Fig. 3, A, B and C). Its purpose is to identify the terrain where mapping data intersects in all 3 methods. This kind of territories was estimated only in 8 elevation zones. Their total area is 0.5926 ha and it is $20 \%$ of all investigative territory (Fig. 4, C). It shows that data is accurate in this territory - it intersects in all three mapping methods.

Elevation errors had been analyzed specifically (Table). Elevation error values given in the Table are compared between all three methods - $\mathrm{Li}^{-}$ DAR, geodetic and analogical. There are three +15 meters errors in the analogical elevation model. It means that there are territories which elevation is 15 meters higher than in geodetic measurements. The most common error value (Mode) is 5 meters. It occurs 30 times and it is

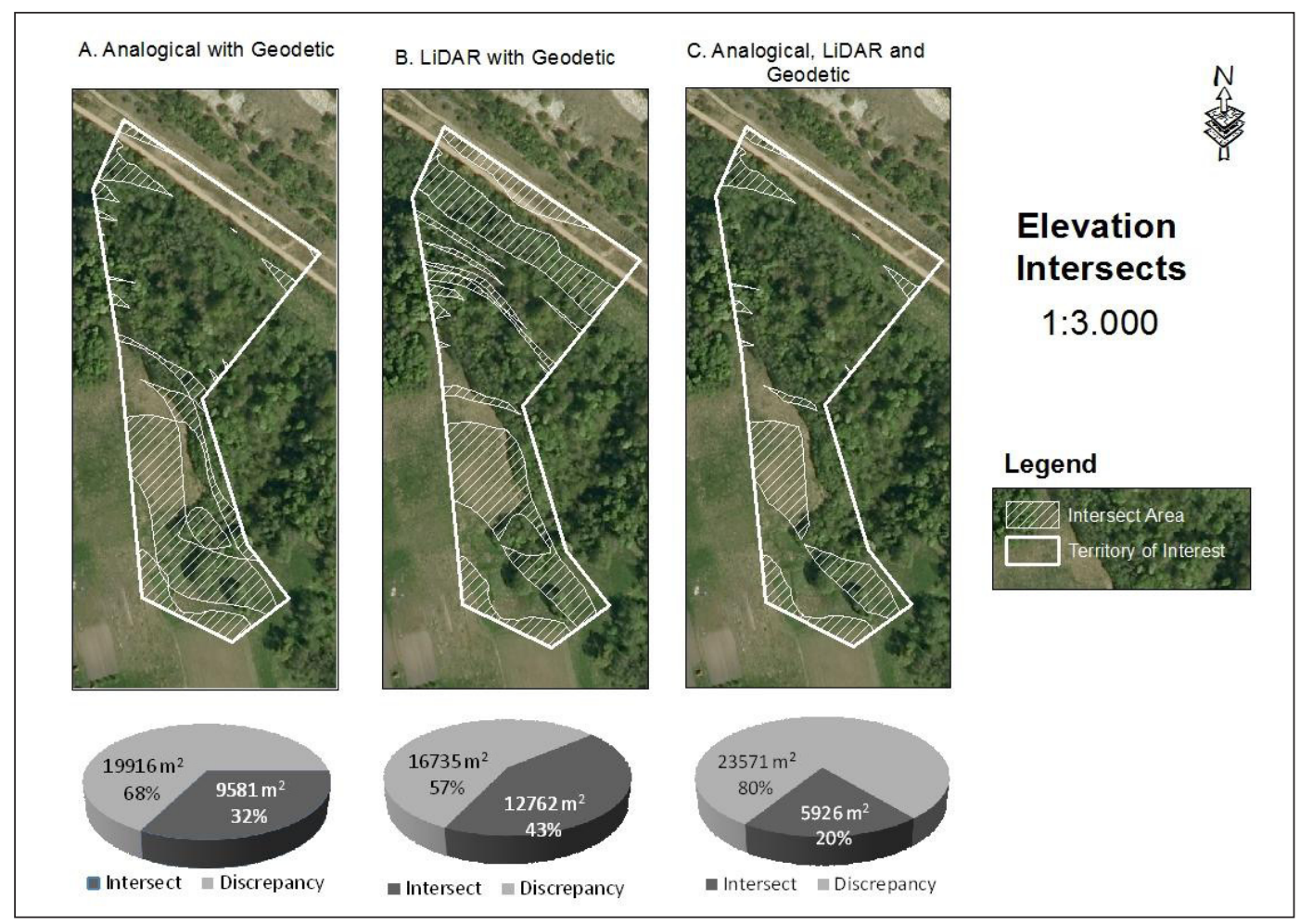

Fig. 4. Elevation intersects 
Table. Data of elevation errors

\begin{tabular}{|c|c|c|c|c|c|}
\hline \multirow[b]{2}{*}{ No. } & \multicolumn{2}{|c|}{ Analogical } & \multirow{2}{*}{\begin{tabular}{|c|} 
Geodetic \\
$\begin{array}{c}\text { Elevation, } \\
\mathbf{m}\end{array}$ \\
\end{tabular}} & \multicolumn{2}{|c|}{ LiDAR } \\
\hline & \begin{tabular}{|c|} 
Elevation, \\
m
\end{tabular} & \begin{tabular}{|c|} 
Error, \\
$\mathbf{m}$
\end{tabular} & & \begin{tabular}{|c|}
$\begin{array}{c}\text { Elevation, } \\
\mathbf{m}\end{array}$ \\
\end{tabular} & $\begin{array}{c}\text { Error, } \\
\text { m }\end{array}$ \\
\hline 1 & 2 & 3 & 4 & 5 & 6 \\
\hline 1. & 80 & 0 & 80 & 80 & 0 \\
\hline 2. & 80 & +5 & 75 & 80 & +5 \\
\hline 3. & 80 & +5 & 75 & 75 & 0 \\
\hline 4. & 75 & -5 & 80 & 80 & 0 \\
\hline 5. & 75 & +5 & 70 & 80 & +5 \\
\hline 6. & 75 & +5 & 70 & 75 & +5 \\
\hline 7. & 75 & 0 & 75 & 80 & +5 \\
\hline 8. & 75 & 0 & 75 & 75 & 0 \\
\hline 9. & 75 & +5 & 70 & 75 & +5 \\
\hline 10. & 75 & +5 & 70 & 70 & 0 \\
\hline 11. & 75 & +10 & 65 & 70 & +5 \\
\hline 12. & 70 & 0 & 70 & 75 & +5 \\
\hline 13. & 70 & -5 & 75 & 75 & 0 \\
\hline 14. & 70 & 0 & 70 & 75 & +5 \\
\hline 15. & 70 & 0 & 70 & 70 & 0 \\
\hline 16. & 70 & +5 & 65 & 70 & +5 \\
\hline 17. & 65 & -5 & 70 & 75 & +5 \\
\hline 18. & 65 & -5 & 70 & 70 & 0 \\
\hline 19. & 65 & 0 & 65 & 75 & +10 \\
\hline 20. & 65 & 0 & 65 & 70 & +5 \\
\hline 21. & 65 & 0 & 65 & 65 & 0 \\
\hline 22. & 65 & +5 & 60 & 70 & +10 \\
\hline 23. & 65 & +5 & 60 & 65 & +5 \\
\hline 24. & 65 & +5 & 60 & 60 & 0 \\
\hline 25. & 65 & +10 & 55 & 65 & +10 \\
\hline 26. & 65 & +10 & 55 & 60 & +5 \\
\hline 27. & 60 & 0 & 60 & 70 & +10 \\
\hline 28. & 60 & 0 & 60 & 65 & +5 \\
\hline 29. & 60 & 0 & 60 & 60 & 0 \\
\hline 30. & 60 & +5 & 55 & 65 & +10 \\
\hline 31. & 60 & +5 & 55 & 60 & +5 \\
\hline 32. & 60 & +5 & 55 & 55 & 0 \\
\hline 33. & 60 & +10 & 50 & 60 & +10 \\
\hline 34. & 60 & +10 & 50 & 55 & +5 \\
\hline 35. & 60 & +10 & 50 & 50 & 0 \\
\hline 36. & 55 & 0 & 55 & 60 & +5 \\
\hline 37. & 55 & 0 & 55 & 55 & 0 \\
\hline 38. & 55 & 0 & 50 & 55 & +5 \\
\hline 39. & 55 & +5 & 50 & 50 & 0 \\
\hline 40. & 55 & +5 & 50 & 45 & -5 \\
\hline 41. & 55 & +5 & 50 & 40 & -10 \\
\hline 42. & 55 & +10 & 45 & 50 & +5 \\
\hline 43. & 55 & +10 & 45 & 45 & 0 \\
\hline 44. & 55 & +10 & 45 & 40 & -5 \\
\hline 45. & 55 & +10 & 45 & 35 & -10 \\
\hline 46. & 25 & 0 & 25 & 30 & +5 \\
\hline
\end{tabular}

\begin{tabular}{c|c|c|c|c|c}
\hline $\mathbf{1}$ & $\mathbf{2}$ & $\mathbf{3}$ & $\mathbf{4}$ & $\mathbf{5}$ & $\mathbf{6}$ \\
\hline 47. & 50 & +5 & 45 & 45 & 0 \\
\hline 48. & 50 & +5 & 45 & 40 & -5 \\
\hline 49. & 50 & +5 & 45 & 35 & -5 \\
\hline 50. & 50 & +10 & 40 & 40 & 0 \\
\hline 51. & 50 & +10 & 40 & 35 & -5 \\
\hline 52. & 50 & +10 & 40 & 30 & -10 \\
\hline 53. & 50 & +15 & 35 & 35 & 0 \\
\hline 54. & 50 & +15 & 35 & 30 & -5 \\
\hline 55. & 45 & 0 & 45 & 40 & -5 \\
\hline 56. & 45 & 0 & 45 & 35 & -5 \\
\hline 57. & 45 & +5 & 40 & 40 & 0 \\
\hline 58. & 45 & +5 & 40 & 35 & -5 \\
\hline 59. & 45 & +5 & 40 & 30 & -10 \\
\hline 60. & 45 & +10 & 35 & 35 & 0 \\
\hline 61. & 45 & +10 & 35 & 30 & -5 \\
\hline 62. & 45 & +15 & 30 & 30 & 0 \\
\hline 63. & 40 & 0 & 40 & 35 & -5 \\
\hline 64. & 40 & +5 & 35 & 35 & 0 \\
\hline 65. & 40 & +5 & 35 & 30 & -5 \\
\hline 66. & 40 & +10 & 30 & 30 & 0 \\
\hline 67. & 35 & 0 & 35 & 30 & -5 \\
\hline 68. & 35 & 0 & 30 & 30 & 0 \\
\hline 69. & 35 & +10 & 25 & 30 & +5 \\
\hline 70. & 30 & 0 & 30 & 30 & 0 \\
\hline 71. & 30 & +5 & 25 & 30 & +5 \\
\hline 72. & 30 & +5 & 25 & 25 & 0 \\
\hline 73. & 25 & 0 & 25 & 30 & +5 \\
\hline 74. & 25 & 0 & 25 & 25 & 0 \\
\hline & & & & &
\end{tabular}

positive or negative. The error that is +10 meters occurs 17 times and it is positive in all cases. There had been estimated 24 cases of absolute intersection, i. e. when both comparing models completely match each other. The average elevation of all errors is 4.4 meters.

While comparing the LiDAR and geodetic data discrepancy, it was measured that the utmost discrepancy of both models was 10 meters and it occurred 10 times. They are both positive and negative. 36 errors consist of 5 meters discrepancy. Both models intersect completely in 28 cases, i. e. error valued at 0 . The average elevation of errors is 0.95 meters.

In summary, the maximum error of 15 meters was estimated in the analogical model. The same model had much more 10 meters errors (17 and 10 cases). The mode of both models is the same - 5 meters, but it is more frequent in the laser scanning model ( 36 and 30 cases). Also the same model had more absolute intersection cases 
(28 and 24 cases). The average elevation of errors is significantly lower in the laser scanning model (0.95 and 4.4 meters). Due to all results mentioned above, it can be confirmed that the laser scanner elevation data is more accurate than the analogical model data. However, the utmost 10 meters error is considerable while comparing to the geodetic model data, it occurs 10 times of 74 cases of comparison.

\section{CONCLUSIONS}

1. After the comparison of elevation data got by geodetic and analogical methods it was estimated that the total intersect area was 0.9581 ha $(32 \%$ of all investigative territory). The utmost elevation discrepancy is 15 meters, Mode 5 meters.

2. When comparing the elevation model made by the geodetic method and LiDAR method, it was estimated that elevation intersected in 1.2762 ha of the territory ( $43 \%$ of all investigative territory). The utmost elevation discrepancy is 10 meters, Mode 5 meters.

3. In comparison of the elevation data of all three methods it was measured that the area of intersection was 0.5926 ha. It is only $20 \%$ of all investigative territory. It can be confirmed that data is accurate in this territory - it intersects in all three mapping methods.

4. The LiDAR elevation data is more accurate than the analogical model data. Nevertheless, the utmost 10 meters error is considerable as compared to the geodetic model data, it occurs 10 times of 74 cases of comparison.

5. Reasons why there is such a discrepancy of horizontals made by three methods might depend on its formation at different time. 50 years are between the horizontals made by analogical and digital methods. So elevations in the territory might be varied because of natural processes and human agricultural activity.

Received 9 October 2013 Accepted 16 December 2013
2. Barazzetti L., Brovelli M., Scaioni M. 2007. Problems related to the generation of true-orthophotos with LIDAR DDDMs. ISPRS Workshop on Laser Scanning 2007 and Silvi Laser 2007. Finland. Vol. 36. No. 3. P. 26-36.

3. Bikuvienè I., Mozgeris G., Žalkauskas R. 2009. The influence of forest cover characteristics on the accuracy of LiDAR based digital terrain model. Rural Development 2009: Transitions Towards Sustainability: The Fourth International Scientific Conference: Proceedings. Vol. 4. P. 217-221.

4. Cunningham D., Grebby S., Tansey K., Gosar A., Kastelic V. 2006. Application of airborne LiDAR to mapping seismogenic faults in forested mountainous terrain, southeastern Alps, Slovenia. Geophysical Research Letters. Vol. 33. No. 20.

5. Janke J. R. 2010. Multicriteria GIS modelling of wind and solar farms in Colorado. Renewable Energy. Vol. 35. P. 2228-2234.

6. Kalantaite A., Putrimas R., Šlikas D. 2010. Erdviniu skenavimo duomenu taikymas vietovés trimačiams modeliams generuoti. Geodezija ir kartografija. T. 36. Nr. 4. P. 151-155.

7. Kazakevičius S. 2000. Žemès matavimo prietaisų kūrimo ir žemèlapių sudarymo istorijos bruožai. Geodezija ir kartografija. T. 26. Nr. 2.

8. Kazakevičius S. V. 2001. Pirmieji Lietuvos teritorijos topografiniai žemèlapiai. Žemetvarka ir hidrotechnika. Nr. 1(105).

9. Kumetaitienè A. 2005. Skaitmeninių reljefo modelių, sudarytų taikant ịvairius pradinius duomenis, tikslumo tyrimas. Geodezija ir kartografija. T. 29. Nr. 3.

10. Ode A., Fry G. 2006. A model for quantifying and predicting urban pressure on woodland. Landscape and Urban Planning. Vol. 77. Issues 1-2. P. 17-27.

11. Satkūnas J., Mikšys R. B., Mikulènas V., Minkevičius V. 2008. Geodinaminiai procesai Vilniaus pilių teritorijoje: šlaitų deformacijos. Vilniaus miesto ir pyliu tyrimai. Vilnius: Lietuvos geologijos tarnyba. P. 62-63.

12. Žalnierukas A., Čypas K. 2006. Žemès paviršiaus skenavimo lazeriu iš orlaivio technologijos analizè. Geodezija ir kartografija. T. 32. Nr. 4. P. 101-105.

13. Žalnierukas A., Ruzgienė B., Kalantaite A., Valaitienè R. 2009. Miestu skenavimo LIDAR metodu tikslumo analize. Geodezija ir kartografija. T. 35. Nr. 2. P. 55-60.

\section{REFERENCES}

1. Baban S. M. J., Parry T. 2001. Developing and applying a GIS-assisted approach to locating wind farms in the UK. Renewable Energy. Vol. 24. P. 2471. 
Agnė Bykovienė, Daiva Gudritienè, Vilma Sinkevičiūtė

HORIZONTALIŲ TIKSLUMO ANALIZE், NUS-

TATYTA SKIRTINGAIS KARTOGRAFAVIMO

METODAIS

Santrauka

Tyrimo tikslas - išanalizuoti skirtingais kartografavimo metodais sukurtų horizontalių tikslumą, sukurti skirtingais metodais sudarytų paviršiaus aukščių tikslumo analizès modelị. Tyrimas buvo vykdomas 3 etapais: 1) teritorijos pasirinkimas ir erdvinių duomenų surinkimas; 2) duomenų apdorojimas; 3) duomenų analizè. Tyrimo objektas - Pyplių kaimo dalies (Kauno r.) reljefas. Tai labai ịvairi, skirtingo išraiškingumo vietové, esanti prie Nemuno.

Palyginus geodeziniu būdu gautus aukščio duomenis su analoginiu, nustatyta, kad sutampančių teritorijų plotas yra 0,9581 ha (32\% visos nagrinejjamos teritorijos). Palyginus geodeziniu būdu gautus aukščio duomenis su LiDAR, nustatyta, kad aukščiai sutampa 1,2762 ha (43\% visos nagrinejjamos teritorijos). Palyginus visais trimis būdais gautus aukščių duomenis, nustatyta, kad sutapimų plotas - 0,5926 ha. Tai sudaro tik $20 \%$ visos nagrinejamos teritorijos. Galima teigti, kad šioje teritorijoje duomenys yra tikrai tikslūs, nes sutampa kartografuojant visais trimis būdais. LiDAR aukščio duomenys yra tikslesni nei analoginiu metodu sudarytame modelyje, tačiau, palyginti su geodeziniu būdu gautais duomenimis, maksimali $10 \mathrm{~m}$ gaunama paklaida yra vis dèlto didelè ir pasitaikanti 10 kartų iš 74 palyginimo atvejų.

Raktažodžiai: aukščių paklaidos, GIS, horizontalių tikslumas, LIDAR, topografinè nuotrauka, modelis, reljefas 